Information Management and Business Review

Vol. 3, No. 6, pp. 360-365, Dec 2011 (ISSN 2220-3796)

\title{
Impact Of After Sale Service Characteristics on Customer Satisfaction
}

\author{
*Ali Iftikhar Choudhary, Syed Azeem Akhter, Muhammad Asif, Rashid Mehmood Choudhry, Zafarullha \\ Siddique, Asif Mughal \\ Iqra University, Islamabad Campus, Islamabad, Pakistan \\ *ali.iftikhar.choudhry@gmail.com
}

\begin{abstract}
Researcher examines the impact of after sale service characteristics on customer satisfaction in home appliance industry of Pakistan. To what extent does characteristics like delivery time, installation of product, warranty time of product, feedback implementations and quality of service provided satisfies customers? In this globalized market, organizations try to differentiate themselves, so they tend to provide value added services to its customers; according their needs and wants. After detail and extensive review of literature researcher found that after sale service is essential in retaining and satisfying customers. Due to limited time, quantitative study is not possible. Practically our study benefitted for the manager of the organization that are mostly related to home appliances, so that they can check the customers trend towards after sale services characteristics i.e. delivery, installation, warranty, service quality and feedback.
\end{abstract}

Keywords: Customer Satisfaction, Service Quality, Warranty, Feedback, Delivery, Installation

\section{Introduction}

Customer satisfaction is considered very important now a day, it shows how firms are committed to provide quality product or services to their customers that eventually increase customer loyalty. Satisfying the customer is one of the basic objectives of the organization, as it is often said that customer is boss and boss is always right, so it means customer is right when he demands for after sale services. After sales service is an emerging concept in the business community. Organizations have to provide better after sale services to retain and satisfy its customer. Making and retaining valuable relationship with customer while using every aspect of taking, retaining and enhancing customer is known as customer relationship management (Kotler and Armstrong, 2010). Through customer relationship management, organizations can achieve their objective of retaining and satisfying customers. Customer satisfaction results in increased demand of product/ service and the organization or brand reputation increases. When organization sell product effectively it has to make effective planning for services after sale, such planning is a part of customer relationship management. After sale, service has been important for organization to compete in the market by using such extended services (Vitasek, 2005).

Front line employees play an extra ordinary role in service value chain, discussed by many authors and researchers. Employees that work at consumer service positions in the organization have to interact with the customers; they have to deliver high satisfaction to them. However, the capabilities of these front-line workers to satisfy customers mainly depend on the environment the organization provides to these employees. Strategic human resource practices that create productivity at work environment are directly related with organizational outcomes i.e. efficiency, quality service and satisfaction of customer. Through many ways customer can be contacted, these may be from physical direct interaction to contact indirectly by letter post, internet and telephone but the main theme is customer interaction (Zomerdijk and de Vries, 2007). It is very important to note that after sale is a key to support marketing performance and to increase customer loyalty, productivity in long run (Saccani, 2006).

The demand of quality is well effective point in the services sector for human. High technical service quality delivery requirement is not only one that demanded, but there is also a quest for extra-quality customer service. When organization offer customers applicable warranty terms then it positively affects the sale and profit because customer become satisfied by warranty assurance. Warranty assurance is highly valuable for 
customer satisfaction as well as for organizations profitability (Murthy, 2004).In sale services, after sale delivery and Installation is very important for customer satisfaction (Irini R., 2008). Different customers have different needs some want that the product to be delivered to their destination at right time and right price, others give value to customers needs and wants, on the other hand poor distribution results negative impression (Kotler and Armstrong, 2010). Such negative impression results in poor seller relationship with consumer. Organizations need to improve relations with customers for effectiveness and to improve their sales turnover, installation of a product without any error results in improved satisfaction of customer this can reduce the chance of damage, error and assures to customer that the product is valuable, errorless and reliable. Installation process must be handled by an experienced professional it also provides delightful post sale service to consumer from organization. Properly managed feedback is important for organization as they came to know that what customer needs from us. What type of changes organization should brought into the product or service line, so that they give more value to customers.

Therefore, services given to consumer after sale are more valuable to satisfy customer needs, after sale service is very important for organization to retain customers for a long time and generate high profitable relationship with organization. Many authors agree that organization can achieve more than their turnover due to after sale service that they provide to customer during a life cycle of a product. Hence, productivity and sales turnover increases and profit generation may be more than product sale (Alexander et al., 2002). Practically our study will benefit the managers of organization related to home appliance industry; they can check customer trend towards delivery, installation, warranty, service quality and feedback. From this, they can see what mostly influence customer satisfaction and what should be properly valued. Objective to conduct this research study is to find out what are the factors or characteristics that might influence customer satisfaction during the services provided after the sale to the customer and to what extent characteristics like delivery, feedback, installation, service quality and warranty mostly likely to affect customer satisfaction.

\section{Literature Review}

After sale service is an increasing concept in many industries and organizations are very dependent on customer, satisfaction as their customer are satisfied their productivity increases otherwise they have to lose the market share. The after sale value line includes timely delivery, installation of the product to customer, good warranty terms and time, enhanced service quality, proper feedback from consumer about the whole service, product and work according to majority recommendations of the consumer. All these after sale value line are considered vital part of after sale service, and through proper usage of this value line organization can increase customer satisfaction and enhance the productivity of the organization (Shaharudin et. al., 2009).

Delivery: Many organizations provide delivery services to its consumers at their doorsteps; they note the address and deliver the product to consumer's destination. Many researcher and authors discuss delivery of the product to be influential and results in increased sale and productivity. Delivery of the product characterized by two dimensions i.e. speed and reliability (Michael, 2001) and ensuring that right product at right time in right quantity from right source delivered to right person at right price . Organization with no strategic plan for delivery of product or service is similar to that person who starts his/her journey without knowing the final destination (Rajesh and Uday, 2004).

Installation: Installation is to fix product, installation is first component of after sale or delivery of the product and is considered to generate more profitable sale. The basic reason for offering installation to consumers is after sale economies, to take competitive advantage and customer demand (Oliva and kallenberg, 2003). When installation goes wrong then it may cost more to the organization as the customer may go for case and organization may have to pay high amount to the customer or spent a lot on the case (Wetmore, 2004).

Warranty: A warranty is assumed an obligation for seller; it is a responsibility for seller and a satisfaction for the buyer that the product will run in long term (Udell and Anderson, 1968). The main purpose of offering warranty is to show that the product will function and last for a longer time compared to competing products. 
To offer warranty organizations must increase the quality of a product to the extent that they can create a reliable and better product and offer long-term warranty to their customer (Kelly, 1988).

Service quality: This is one of the main category where organization face problems these days, this problem is mainly in service sector where consumer often complaint about the quality of service. It happens when consumer use the product or service and feels uncomfortable with it. It also arise when consumer do not like the quality of after sale service like warranty, installation and delivery services. To retain and satisfy consumer to greater extent it is necessary that service quality should be high (Cronin, J. and Taylor, S. 1992). Functional quality is very important dimension in services and dimensions of quality are interrelated (Christian, 1984).

Feedback: Customer feedback is considered very important these days. Organizations are more customer oriented therefore they want to know customer needs in the product or service. Such information can be useful in designing products and services that are more useful for customers they tend to purchase their product and hire their services. When a customer is dissatisfied with the product or service, there are two options available to the customers. The first one is to leave the particular product and chose among the other products available. The second option is to make suggestions or complaints for the same product; this response from the customers is vital for the organization to improve (Barlow and Moller, 1996). Feedback can be collected through different procedures like comment cards, toll free numbers, through telephone or through internet (Sampson, 1998)

Customer satisfaction: Organizations are more customers oriented they have to satisfy their customers, the satisfied customer enables organization to retain more customers, which results in high sale turnover, higher productivity and profit to the organization. Customer satisfaction is related with loyalty of the customer and financially stable performance of the firm (loveman, 1998). Customer satisfaction must be the primary objective of the organization for success and growth (Pertson and Willson, 1992).

Relationship: Delivery of product/service with customer satisfaction: Proper strategy for Delivery of service towards the customer enhances the customer satisfaction and loyalty towards the product (Rajesh and Uday, 2004). Due to technological advancement the product life cycle time shrinks, so organizations must ensure timely delivery of the product, for this IBM introduces the integrated product delivery framework. Integrated delivery framework provides four options for managing delivery, product program management, enterprise release management, quality and test lab management and definitive software library. Delivery of the product enhances the customer satisfaction excessively (Shaharudin et. al., 2009). For delivery of service and product Dealers, independent Service center, franchised Service center and mobile service centers can be used (novoally.com). Delivery of the product characterized by two dimensions i.e. speed and reliability (Michael, 2001) and ensuring that right product at right time in right quantity from right source delivered to right person at right price on right destination. Delivery of product and service within time to the customer increases customer satisfaction.

Installation of the product/service with customer satisfaction: Installation of the product at customers own destination enhances customer support activities so it further enhance the satisfaction of customer in a sense that within purchasing cost company offer installation services to customer which is beneficial to both customer and organization (Shaharudin et. al., 2009). The basic reason for offering installation to consumers is after sale economies, to take competitive advantage and customer demand (Oliva and kallenberg, 2003). Installation of the product at customer's doorstep, increases customer satisfaction

Warranty of the product/service with customer satisfaction: With a Better warranty terms a customer can attain improved benefit of purchasing cost for repair or technical damage of the product this results in greater sale and profit. Long warranty time is also one of the bundles of satisfaction the consumer (Shaharudin et. al., 2009). A warranty is assumed an obligation for seller; it is a responsibility for seller and a satisfaction for the buyer that the product will run in long term (Udell and Anderson, 1968). Many weak organizations offer better warranty terms than their competitors to gain competitive advantage. Organizations consider brand loyalty is result of customer satisfaction. Therefore, credibility gap can be filled 
through offering better warranty terms (Fisk, G. 1970). Valuable warranty terms and time increases satisfaction of customer.

Quality of service /product with customer satisfaction: Quality of the service helps in determining the organizations global delivery system for the product or service, customer satisfaction and quality of service have causal relationship with each other and service quality influence the future purchase behavior $(\mathrm{H},-\mathrm{H}$. $\mathrm{Hu}$ et al., 2009). To retain and satisfy consumer to greater extent it is necessary that service quality should be high (Cronin, J. and Taylor, S. 1992). Quality of service/product has positive impact on customer satisfaction.

Customer feedback with customer satisfaction: Proper feedback from customers and changes in products according to the feedback increases satisfaction of the customer and mould the product to customer's requirement consumer become loyal for the brand of the product. Feedback increases the interaction of organization and consumer, organization get many creative responses through feedback (Barlow and Moller, 1996). To make suggestions or complaints for the product, response from the customers is vital for the organization to improve (Barlow and Moller, 1996) the product or service for customers.

Properly management customer feedback increase customer satisfaction.

\section{Fig.1: Proposed Model}

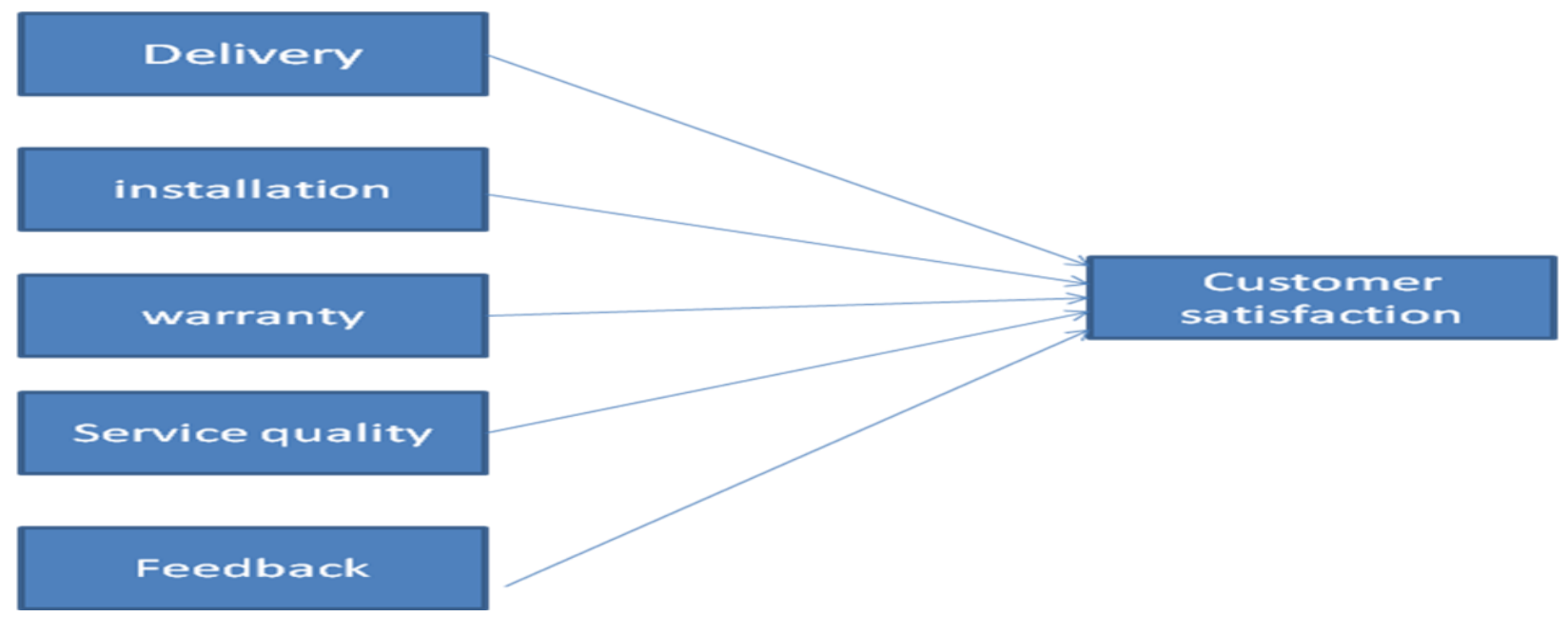

\section{Discussion}

A performance evaluation indicates the degree to which a goal or objective has been achieved. Indicators depend on data collection/reporting and clear descriptions of company targets/goals. Objective to conduct this research study is to find out what are the factors or characteristics that might influence customer satisfaction during the services provided after the sale to the customer and to what extent characteristics like delivery, feedback, installation, service quality and warranty mostly likely to affect customer satisfaction. Satisfied customer is like an asset for the organization. The manager must be aware that how to satisfy the customer and get his loyalty. Profitability is the main objective of every organization, they tend to maximize it. The empirical findings of past papers showed that service delivery had a greater $t$ value of 5.66 compared to that of installation 5.047 and warranty 4.158, the value of chi-square 533.149 and $\mathrm{df}$ is 91 (Shaharudin et. al., 2009). All these factors have been found to have a significant effect on customer satisfaction that is coherent to the findings of this study. After sales service has a more than three times affect of product life cycle as compared to product sales itself, and has empirically found to have greater impact on profitability (Alexander et al., 2002). 
While seeing the impact of after sale service characteristic on customer satisfaction, quality of the product comes first in the mind that what customer perceived about the product or service quality and to what extent it is provided to the customer. Quality of the product or service mainly depends on the customer's purchasing power, and prevailing patterns in the industry. Many multinationals sell their same products or provide services to different areas with differences in quality at different costs. Organizations often want to create differences among other organizations in the industry so that is why they tend to use such characteristics i.e. delivery and installation, for just creating differences. In this modern era customer want to get, some value added services as well, so mostly these day customers decide on internet that what to buy and order the concerned organization for the product. Organizations deliver \& install such product at the doorstep of the customer without any or with low extra charges. Economic and industrial conditions played an important role towards after sale services. Mostly high competition in an industry brought such services in the market and organizations try to look different from the rest. That went purely in the benefit of the customers, on other hand it costs more for the organization. Organizations with strong financial background and effective management of resources afford to provide such services to satisfy customers for obtaining sustainable competitive advantage.

\section{Conclusion and Recommendations}

It is important that the company to adopt a good after-sales service management to enhance the effectiveness and efficiency to serve the customer. For example, by implementing extensive customer relationship management (CRM) with sophisticated software and analytical tools, this can help to integrate customer information and build stronger capabilities in delivery, installation and warranty. Secondly, companies need to improve on the inventory management by keeping acceptable safety stock to avoid the delay in product delivery to the customer. Furthermore, it must always keep the lead-time at the minimum possible as to meet the needs and wants of the customer. A good distribution system is required to ensure that the product can reach the customer at the right time and place. Thirdly, pertaining to installation, the company must always train their staff to give cohesive and reliable services to the customers. Here, a good attitude towards working together throughout the installation process with the customer is needed so that the customer will be happy and delighted with the service. Fourthly, there is a need to respond within a reasonable and acceptable period to the customer regarding the warranty claim. The company should not delay the claim made by a customer and try to fulfill it promises either by repairing or by replacing with a new product. Fifthly, continuous improvement is required through integrated functional activities in order to produce high quality products that in turn can lead to customers' high satisfaction and confidence. Finally, feedback from customer about the quality and service of the product is essential to convert the product line and service according to needs and wants of customers. All departments be it Marketing, Finance, Operations and Human Resource must work together to achieve the mission, vision and objectives of the company.

Practically our study will benefit the managers of organization related to home appliance industry; they can check customer trend towards delivery, installation, warranty, service quality and feedback. From this, they can see what mostly influence customer satisfaction and what should be properly valued. Future study may focus on factor like customer needs, customer loyalty, product differentiation and price of product that also enhance customer satisfaction. Due to limited time quantitative study cannot made possible, that is why in

this study researchers only considered some measureable characteristics of after sale service that affects customer satisfaction.

\section{References}

Alexander, W. L., Dayal, S., Dempsey, J. J. \& Vander-Ark, J. D. (2002). The secret life of factory service centers. The McKinsey Quarterly, 3, 106-115.

Barlow, J. \& Moller, C. (1996). A complaint is a gift: using customer feedback as a strategic tool. San Francisco: Berrett-koehler publisher Inc.

Christian, G. (1984). A Service Quality Model and its Marketing Implications. European Journal of Marketing, 18(4), 36-44. 
Cronin, J. \& Taylor, S. (1992). Measuring service quality: A Reexamination and extension. journal of marketing, 56, 55-68.

Customer life cycle management (n.d.), retrieved from http://www.novoally.com).

Fisk, G. (1970), Guidelines for Warranty Service after Sale. Journal of marketing, 34(1), 63-67.

Hu, H., Kandampully, J. \& Juwaheer, T. (2009). Relationships and impacts of service quality, perceived value, customer satisfaction, and image: an empirical study. The service industries journal, 29(2), 111-125.

Irini D. R. (2008). After-sales service quality as an antecedent of customer satisfaction, the case of electronic appliances. Journal Managing Service Quality, 18(5), 512-527.

Kelly, C. (1988). An Investigation of Consumer Product Warranties as Market Signals of Product Reliability. Journal of academy of marketing science, 16 (2), 72-78.

Kotler, P. \& Armstrong, G. (2010). Principles of Marketing (13 Ed.), NJ, Pearson Prentice Hall.

Loveman, W. (1998). Employee Satisfaction, Customer Loyalty, and Financial Performance an Empirical Examination of the Service Profit Chain in Retail Banking. Journal of service research, 1(1), 18-31.

Michael, M. (2001). Supply chain complexity and delivery performance: an international exploratory study, Supply Chain Management: An International Journal, 6(3), 106 - 118.

Murthy D. N. P. (2004). Product warranty logistics: Issues and challenges. European Journal of Operational Research, 156(1), 110-126.

Saccani, N. (2006). The role and performance measurement of after-sales in the durable consumer goods industries: an empirical study. Journal of Productivity and Performance Management, 55(3), 259-283.

Olive, R. \& Kallenberg, R. (2003). Managing the transition from products to services. International journal of service industry management, 14(2), 160-172.

Pertson, R. \& Willson, W. (1992). Measuring Customer Satisfaction: Fact and Artifact. journal of academy of marketing science, 20(1), 61-71.

Rajesh, K. \& Uday, K. (2004). A conceptual framework for the development of a service delivery strategy for industrial systems and products. Journal of Business \& Industrial Marketing, 19(5), 310-319.

Sampson, S. (1998), Gathering customer feedback via the Internet: instruments and prospects, industrial and management data system, 98(2), 71-82.

Shaharudin, M., Elias, S. \& Mansor, S. (2009). Factors Affective Customer Satisfaction In After Sale Service Of Malaysian Electronic Business market. Canadian Social Science, 5(6), 10-18.

Udell, J. \& Anderson, E. (1968). The product warranty as an element of competitive strategy. Journal of marketing, 32(1), 1-8.

Vitasek, K. (2005). Supply Chain \& Logistics Terms and Glossary, Belevue, WA; Supply Chain Vision.

Wetmore, P. (2004). The Seybold report, Analyzing-publishing technologies, 4(7), 16-19

Zomerdijk, L. G. \& De-Vries, J. (2007). Structuring front office and back office work in services delivery systems. International Journal of Operations \& Production Management, 27(1), 108-131. 